\title{
ZAKAT MANAGEMENT AND POVERTY ALLEVIATION IN INDONESIA
}

\author{
Maghfirah \\ Faculty of Sharia and Law, Universitas Islam Negeri Sultan Syarif Kasim, \\ Indonesia \\ Email:maghfirah@uin-suska.ac.id
}

Abstract

Zakat is potential to reduce the poverty number in Indonesia. The professional and effective management is the main key to achieve this target. This article analyzes the effectiveness of zakat distribution in Badan Amil Zakat Nasional (Baznas), Pekanbaru City in accordance with the Law No. 23 of 2011. The article is based on the doctrinal legal research with sociological approach. The data is collected through interview, documentation, and observation by analyzing the data in inductive, deductive, and comparative ways. The result reveals that zakat management in Baznas Pekanbaru is not effective yet in its effort to improve mustahiq (zakat receivers) economy. Of all effective strategies to collect the funds are: 1) government total intervention in collecting and distributing the zakat funds, 2) socialization to the community to pay zakat via Baznas, 3) Improving Baznas' human resources and management, 4) Implementing the expansion concept in zakat obligation. Meanwhile, the effective strategy in zakat funds distribution is classifying mustahiq into two groups i.e. mustahiq jabariah and mustahiq khiyariah with different model approach.

Zakat berpotensi besar menjadi sarana mengurangi angka kemiskinan di Indonesia. Pengelolaan yang professional dan efektif menjadi kunci utama mencapai tujuan ini. Artikel ini bertujuan menganalisis efektivitas penyaluran zakat di Badan amil zakat nasional Pekanbaru menurut Undang-Undang No. 23 Tahun 2011. Artikel ini berdasarkan penelitian bukum diktrinal dengan pendekatan sosiologis. Metode pengumpulan data adalah wawancara, dokumentasi dan observasi dengan analisis data secara induktif, deduktif dan komparatif. Hasil daripenelitian ini menjukkan babwa manajemen zakat di Baznas Pekanbaru belum efektif dalam upaya meningkatkan ekonomi mustahiq. Adapun strategi efektivitas penghimpunan dana yaitu; (1) intervensi pemerintah secara menyelurub dalam penghimpunan dan penyaluran 
dana zakat, (2) sosialisasi kepada masyarakat agar berzakat melalui Baznas, (3) meningkatkan Sumberdaya Manusia dan manajemen Baznas, dan (4) menerapkan konsep perluasan dalam kewajiban zakat. Sedangkan strategi efektivitas distribusi dana zakat adalah melakukan pengklasifikasian mustahiq kepada dua kelompok, yakni mustahiq jabariah dan mustahiq khiyariah dengan model pendekatan yang berbeda

Keywords: Badan Amil Zakat, poverty, zakat.

\section{Introduction}

Islam has given great attention to poverty alleviation. This is proven in history, when Muslims were still oppressed minority, did not have government and political organization, the Quran had given full attention to social problems and poverty reduction. ${ }^{1}$ In the history of Islamic law, zakat (Islamic term for alms/donation) was required in Medina as written in the Surah Makiyah where nishab had been determined, people who collected and distributed the zakat had been arranged, and the state was responsible for managing it. ${ }^{2}$

Poverty phenomenon is one of complexities in Indonesia. Poverty as a social reality needs to get serious attention from the government as a form of creating a civilized state as declared in the Preamble of the 1945 Constitution (known as UUD 1945). Therefore, one alternative solution is through optimizing the management of zakat funds. The Law No. 38 of 1999, which is now improved in the Law No. 23 of 2011 concerning Management of Zakat, is one of the supporting elements in poverty alleviation through zakat management arrangements into positive legal regulations in Indonesia. ${ }^{3}$ The Article 5 paragraph (2) and (3) of the Law No. 38 of 1999 asserts zakat management's aims; (1) improving the religious institutions' function and role in an effort to realize community welfare and social justice, and (2) increasing the usefulness and effectiveness of zakat. Furthermore, the Article 3 of the Law No. 23 of

1 The Quranic formulas are sometimes summed up with the words "feed and encourage the poor", and sometimes with the phrase "draw out the provision of Allab", grant the rights of the poor, and get on the go, pay for zakah," and other formulas. Yusuf Qardawi, Fiqh al-Zakatt, translated by Salman Harun, et.al,. Ed. 6 (Bogor: Pustaka Litera Antar Nusa, 2002), 50; Ahmad Warson Munawwir, Al-Munawwir: Kamus Arab Indonesia (Yogyakarta: Pondok Pesantren al-Munawwir, 1984), 615.

2 Yusuf Qardawi, Fiqh al-Zakät..., 60.

3 The goals of the Indonesian people are: "to form an Indonesian government that protects the entire Indonesian nation and all of Indonesia's blood and to promote public welfare, educate the nation's life, and participate in carrying out world order based on independence, eternal peace and social justice". The $4^{\text {th }}$ Paragraph of the Opening of UUD 1945. Elsi Kartika Sari, Pengantar Zakat dan Wakaf (Jakarta: Grasindo, 2006), 4. 
2011 adds that zakat management aims at (1) increasing the effectiveness and efficiency of services in the zakat management, and (2) increasing zakat benefits to realize community welfare and poverty reduction. ${ }^{4}$

Both the Law No. 38 of 1999 and the Law No. 23 of 2011 firmly express that zakat management aims to actualize community welfare and poverty reduction. If we look at the zakat potential in Pekanbaru in 2013, 84\% (819,255 people) of the total population (975,304 people) there is Muslim. This number is very extraordinary and it might be a good opportunity when their zakat is managed optimally. If only $30 \%$ (245,776 people) of Pekanbaru citizens have the status as murakki and donate IDR 1 Million each, then IDR 245,776,000,000 will be highly likely collected. If half of the funds are channeled through Badan Amil Zakat Nasional (shortened as Baznas) Pekanbaru, Baznas revenue will reach IDR $122,888,000,000$ or if it is only a quarter, then the revenue reaches IDR $61,444,000,000$.

Based on the data from the Statistics Indonesia (locally known as Badan Pusat Statistik) of Pekanbaru, in 2013 there were 22,741 poor people (4.3\% of the city's total population). ${ }^{5}$ The number includes non-Muslim communities. The poor from Muslim population is 19,102 families which is $84 \%$ of the total poverty. Seeing the number of poor Muslim population and being associated with the amount of potential zakat in Pekanbaru, then poverty alleviation efforts can be implemented. Pekanbaru is one of the areas that have Baznas as zakat institution. In 2013 the receipt of zakat only reached IDR 2,130,466,484. The zakat funds were received from several sources; (1) Zakat Collecting Unit (UPZ) from Pegawai Negeri Sipil (PNS or Civil Servants) in various offices in the regional government and Ministry of Religion of Pekanbaru, gathers IDR 1,942,655,637, (2) individuals muzakeki (communities obliged to pay zakat) donates the total IDR $177,685,500$, and (3) profit sharing funds from Islamic Banks collects IDR 10,125,347.

Seeing the nominal received by Baznas Pekanbaru from the sources which do not reach large numbers, it is relatively small when compared to the potential of Pekanbaru citizen. Therefore, the purpose this article is to analyze the effectiveness of zakat management to improve the mustahiq (the zakat beneficiaries) economy in Baznas Pekanbaru. The management of zakat

4 Kantor Dinas Kependudukan dan Catatan Sipil Pekanbaru, Statistik Jumlah Penduduk Kota Pekanbaru Tahun 2013; Suparman Usman, Hukum Islam Asas-asas dan Pengantar Studi Hukum Islam Dalam Tata Hukum Indonesia (Jakarta: Gaya Media Pratama, 2002), 164.

5 Badan Pusat Statistik Pekanbaru, Data in 2013. The total of poor citizen in Pekanbaru has already included non-Muslim communities. 
in the discussion is the aspect of receiving and distributing zakat carried out by Baznas Pekanbaru.

\section{Research Methods}

This research uses a juridical approach in the form of empirical studies to find theories of the process of law occurrence and operation in society. This research typology is also called socio legal research. Analytical descriptive is also applied to obtain information about the effectiveness of zakat management in improving the mustahiq economy in Baznas Pekanbaru. The researcher chooses samples from several population for this study; 6 of 25 Baznas Pekanbaru staffs, 100 of 889 Muzakki performing zakat in Baznas Pekanbaru, and 43 of 387 mustahiq. The samples were chosen using purposive sampling technique, namely the selection of a group of subjects on certain characteristics or traits that were considered to have a closely related connection with the population. Several acts were done to collect the data; (1) interview, i.e. asking questions directly to the respondent regarding zakat management problems, optimizing the receipt and distribution of zakat in Baznas Pekanbaru, (2) documentation, and (3) observation. The data analysis was carried out qualitatively using juridical method, in the form of statement, both from the method of determining the law and the substance of the law itself. The technique of using juridical analysis is to analyze the obtained data using common methods in the study of legal science, such as the interpretation and construction of law, and linking with the norms, principles and methods that govern.

\section{Analysis of the Use of Funds in Baznas Pekanbaru The Use of Zakat Funds}

The use of zakat funds in Baznas Pekanbaru is classified into two programs. First, the consumptive program is distributed to mustabiq in three criteria, namely: 1) Program Pekanbaru Cerdas, which is a funding program for education, 2) Pekanbaru healthy program, which is a funding program for medical expenses, and 3) Program Pekanbaru Peduli, the funding program for the disaster victims such as floods, fires, and others. Second, productive programs are distributed in the form of Program Pekanbaru Makmur, which provides funds for venture capital or additional capital for small businesses. However, since the funds provided are relatively small, it is then given as assistance; and since the business owners have yet made the significant turnover, the zakat funds could not free them 
from economic hardship. ${ }^{6}$ The distribution of zakat by Baznas Pekanbaru both consumptive program and productive programs are not optimal and efficient. ${ }^{7}$ This is influenced by several things. First, the funds provided are temporary and have not been organized. ${ }^{8}$ Zakat becomes the first foundation in building social security or takaful (mutual help) in life prevailing in Islamic society. ${ }^{9}$ The author criticizes the zakat distribution model that it is mustahiq picking up the zakat. In fact, the Islam concept in the zakat distribution is to deliver it to the houses or residences of people in need without burdening them to come and get the alms by themselves. ${ }^{10}$ The submission of zakat affairs to the state which is then managed by 'amil (an institution managing zakat collection and distribution), has moral philosophy that is to maintain the honor of mustahiq from compassion and so as not to hurt them by listening to hurtful words. ${ }^{11}$

Second, the zakat distribution model prefers the quantity of mustahiq rather than the quantity of provided assistance. Islam teaches that zakat is not just temporary assistance for the poor; that after using the alms, they are abandoned,

6 Faridah Prihartini, et.al., Hukum Islam Zakat dan Wakaf; Teori dan Prakteknya di Indonesia (Jakarta: Papan Sinar berkerjasama dengan Badan Penerbit FHUI, 2005), 50

7 The productive zakat scheme also experienced a decline in Baznas Tanah Datar, even though this scheme has the potential to change the economic status of mustabiq. Widi Nopiardo. Mekanisme Pengelolaan Zakat Produktif Pada Badan Amil Zakat Nasional Tanah Datar. Jurnal Ekonomi dan Bisnis Islam. Vol 1, No 2 (2016): 185-196; Havis Aravik. Esensi Zakat Sebagai Instrumen Finansial Islami Dalam Pandanga Muhammad Nejatullah Siddiqi. Jurnal Economica Sharia. Vol 2, No 2 (2017): 101-112; In addition to the consumptive distribution of zakat, a productive distribution model can be used, namely giving alms to the poor in the form of venture capital or business funds so they can use it as a source of livelihood. Several empowerment models can be divided into two groups; structural and cultural steps. Structural steps are more emphasized to specific institutions that handle them well and cultural steps are more emphasized to individuals, both individuals who are expected to be one of the subjects of poverty alleviation and empowerment of the poor. Muhammad Istan. Pengentasan Kemiskinan Melalui Pemberdayaan Ekonomi Umat Menurut Perspektif Umat. Al-Falab: Journal of Islamic Economics. Vol 2, No 1 (2017): 81-99; Jumadin Lapopo. Pengaruh ZIS (Zakat, Infak Sedekah) dan Zakat Fitrah Terhadap Penurunan Kemiskinan di Indonesia Periode 1998-2010. Jurnal Media Ekonomi. Vo 20, No 1 (2012): 83-108.

8 Zainuddin Ahmad bin Abdul Lathif al-Zabidi, Al-Tajrid al-Shabih li Ahqdits al-Jami' al-Shabih, Translated by Cecep Syamsul Hari dan Tholib Anis, Ringkasan Shabih al-Bukbari, Ed 4 (Bandung: Mizan, 2002), 282.

9 Yusuf Qardawi, Fiqh al-Zakät, translated by Salman Harun, et.al,. Ed. 6 (Bogor: Pustaka Litera Antar Nusa, 2002), 742-743.

10 Yusuf Qardawi, Daur al-Zakät, fi Tllaj al-Musykilat al-Iqtishadiyah, Transleted by Sari Narulita, Spektrum Zakat, Dalam Membangun Ekonomi Kerakyatan. Ed. 1 (Jakarta: Zikrul Hakim, 2005), 24-25

11 Yusuf Qardawi, Daur al-Zakät..., 742-743; M Quraish Shihab, Membumikan al-Qur'an (Bandung: Mizan, 1992), 325. 
and then return to poverty. ${ }^{12}$ The success of zakat management in realizing its aims and objectives will greatly influence the lives of Muslim communities, including resolving poverty, providing comprehensive social security, making insurance for people in need, building togetherness between all individuals and groups, clarifying society from the causes of malice and hatred. ${ }^{13}$

Third, the distribution of productive zakat has not been based on a comprehensive study and has not been supervised. ${ }^{14}$ It is because Baznas has not implemented the Article 29 of the Verdict of Indonesian Ministry of Religion No. 373 of 2003 concerning the Implementation of the Law No 38 of 1999 concerning Zakat Management, namely (a) conducting a feasibility study; (b) determining the types of productive business; (c) providing guidance and counseling; (d) conducting monitoring, control and supervision; (e) conducting evaluations; and (f) reporting. ${ }^{15}$ Since the mustahiq of Program Pekanbaru Makmur has not been based on feasibility study, has not received guidance and counseling, no monitoring, control, supervision, and no evaluation by the Baznas, and, even worse, there is no reporting of business development, consequently, they do not use the fund according to the initial agreement and the development of their business is unknown. The task of the 'amil is to record the number of mustahiq,

12 The essence of zakat covers moral, social and economic fields. In the moral field, zakat removes the greed of the rich. In the social sector, zakat aims to eradicate poverty from the community. Furthermore in the economic field, it becomes a deterrent to the accumulation of wealth in a small proportion of humans. Nurul Huda, et.al., Zakat Perspektif Mikero-Makro: Pendekatan Riset, Ed 1 Jakarta: Prenada Media Group, 2005), 10-11; M. Ali Hasan, Zakat dan Infak, Salah Satu Solusi Mengatasi Problema Sosial di Indonesia, Ed 1 (Jakarta: Prenada Media Group, 2006), 18-24.

13 Yusuf Qardawi, Daur al-Zakät...., 55; Cholid Fadlullah, Mengenal Hukum ZIS (Zakat dan Infaq/ Sedekab) (Jakarta: Bazis DKI, 1993), 12; Afzalur Rahman, Doktrin Ekonomi Islam (Yogyakarta: Dana Bakti Wakaf, 1996), 250.

14 To alleviate poverty, the distribution of zakat is more focused on long-term distribution and has implications for the increase of mustabiq's assets. The zakat distribution is productive, for example the distribution of zakat that is traditional and creative. See Noor Amelia. Analisa Potensi Zakat Dalam Upaya Pengentasan Kemiskinan Di Kalimantan Selatan. Jurnal Humaniora Teknologi. Vol 2, No 1 (2016): 1-9; Syarifuddin. Pendayagunaan Zakat Mal Dalam Mengentaskan Kemiskinan (Studi Kasus mustahiq Kelurahan Manggala Kota Makassar. Urnal Ekonomi Syariab Indonesia. Vol 8, No 1 (2018): 14-22; Senda Paradilla. Revitalisasi Pengelolaan Zakat pada Badan Amil Zakat Nasional (BAZNAS) Kota Palopo dalam Meningkatkan Kesejahteraan Mustahik. Dinamis: Journal of Islamic Management and Business. Vol 2, No 1 (2019): 23-36; Zusiana Elly Triantini. Perkembangan Pengelolaan Zakat di Indonesia. Jurnal Al-Ahwal. Vol 3, No 1 (2010): 87-100.

15 Help chosen people to make a directed improvement, unite one sentence of da'wah only to Allah, strengthen faith only to Allah, unite the hearts of all people to always worship Him, as well as the intentions and purposes of others Zakat which overshadow the interests of Islam, the country and also its citizens and this success depends on a good understanding of zakat, as well as its application through existing management. Muhammad Daud Ali, Sistem Ekonomi Zakat dan Wakaf Jakarta: UI Press, 1998), 40. 
how much their needs and the amount of costs that can meet their needs. ${ }^{16}$ The role of zakat is not just giving some money or a few liters of rice which is enough to support recipients of zakat in a few days or weeks, and after that, they will return to their original condition and expect to receive alms again. Actually, the zakat's role lies in how a recipient is able to support himself with the capabilities he has. So that he has a steady income that is sufficient for his life, so he does not need to depend on others. Therefore the zakat distribution must be in accordance with the requirements needed. ${ }^{17}$

\section{The Use Of Infaq And Charity Funds}

Receipt of infaq (charity) in Baznas Pekanbaru is relatively small, amounting to IDR $80,622,729$. This is decreasing by $0.15 \%$ or IDR $20,488,314$ from the previous year which reached IDR 101,111,043. The distributed infaq funds was IDR 73,137,903 in the form of loans called Qard al-Hasan (benevolent loan). In 2013, the nominal range given is IDR 1,500,000 to IDR 7,000,000. Because mustabiq who got the qard al-hasan was based on a feasibility study and has not received guidance and counseling, there has been no monitoring, control, supervision, and no evaluation by Baznas. As a result, there is also no reporting of business development by mustahiq. If the loan has defaulted, the qard al-hasan method is no longer a solution to mustahiq's financial problems; instead it causes new problems i.e. mustabiq being in debt. ${ }^{18}$

\section{The use of 'amil funds}

Baznas ('amil) managers are employees that should be paid according to his work load; not too small and not too excessive. According to Shafi'i, 'amil was given zakat as much as the rest of the group, because it was based on his opinion which equated the parts of all the mustahiq groups. If the wage is greater than the portion, it must be taken from assets outside of zakat. Jumbur (majority) ulama argued, 'amil was given from zakat according to his rights, as contained in the Quran, although it was greater than the prescribed limits. It is because Shaf'i's opinion was considered relevant to the upholding of the poor and mustahiq's needs. That opinion is also in line with the hadith regarding tax to pay the officers. ${ }^{19}$ Amil is

16 Article 29 of the Verdict of Indonesian Ministry of Religion No. 373 of 2003 concerning the Implementation of the Law No 38 of 1999 concerning Zakat Management.

17 Muchsin, Masa Depan Hukum Islam di Indonesia (Jakarta: STIH Iblam, 2004), 41

18 M. Ali Hasan, Zakeat dan Infak....., 23.

19 Muhammad Rashid Ridha, Tafsir al-Manar. Jil 10 (Mesir: al-Manar, 1368 H), 513; Warkum Sumitro, Hukum Islam di Tengah Kehidupan Sosial Politik (Yogyakarta: Bayu Media, 2005), p. 230; Mardani, Hukum Ekonomi Syariah di Indonesia (Jakarta: Refika Aditama, 2010), 27; Akhmad Mujahidin, Ekonomi Islam 
still given alms even though he is rich, because what is given to him is his work compensation, not in the form of help for those in need. Abu Daud narrated the hadith from the Prophet Muhammad (PBUH):

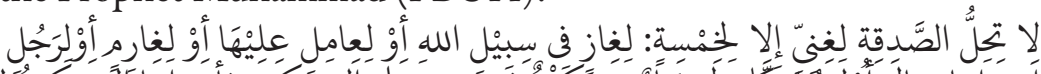

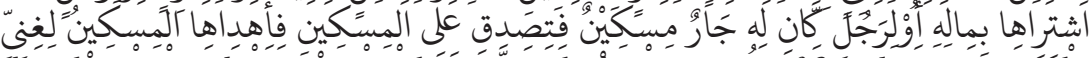
"Sadaqah" may not be given to rich "man with the exception of five classes: Óne w' who fights in Allah's path, or who collects it (the sadaqah), or a debtor, or a man who buys it with his money, or a man who has a poor neighbor who has been given sadaqah and gives a present to the rich man." (HR Abü Dawwud). ${ }^{20}$

\section{The Effectiveness of Zakat Distribution in Baznas Pekanbaru in Improving Mustahiq Economy}

The amount of zakat funds use in 2013 was IDR 1,833,026,859, an increase of $294.96 \%$ or IDR $1,369,024,314$, from the last year which was only IDR $464,102,545$. The entire use of these funds is distributed to mustahiq zakat in the form of consumer and productive financing. Forms of consumer financing are divided into several programs.

\section{Consumptive Program \\ Program Pekanbaru Cerdas}

Program Pekanbaru Cerdas is a form of zakat distribution aiming at helping children's education from poor families. In 2013 the amount of distribution for this program was IDR 895,110,991. The nominal range of Program Pekanbaru Cerdas is IDR 900,000 up to IDR 2,000,000. The varying nominal received by mustahiq, according to the head of Baznas Pekanbaru Dr. Akbarizan, is due to the different needs of mustahiq. The money donated does not cover all educational fees since it is only an aid. Baznas has not been able to meet all the educational needs of mustahiq in Program Pekanbaru Cerdas because of the limited amount of zakat collected by Baznas. ${ }^{21}$

Some mustahiq zakat said the assistance provided by Baznas Pekanbaru had eased some of the costs of their school needs, such as purchasing uniforms, books, and committee money. ${ }^{22}$ In reality, although the money given is for mustahiq's

(Jakarta: Raja Grafindo Persada, 2013), 66.

20 Ibn Hajar al-'Asqalani, Bulügh al-Maräm, Translated by Moh. Machfuddin Aladip (Semarang: CV. Toha Putera, t.th), p. 278; Maulidizen, Ahmad. Economic Thought of Ibn Taimiyah and Relevance to the

World Economic and Community Economic System. Esensia: Jurnal Ilmu-ilmu Ushuluddin. Vol 20, No 2 (2019): 131.

21 Dr. Akbarizan, Daily Chairman of the Pekanbaru City Baznas, Interview, on 20 August 2015; In Pekanbaru.

22 Nur'aini, Zulkifli, Dasril and Rohani, Mustahiq Zakat, Interview, 10 August 2014. 
educational expenses, some of them also give it to help their parents to meet the daily needs, such as buying rice, side dishes and some also use it for paying debts that are due. ${ }^{23}$

Mustabiq who wants to receive the fund of Program Pekanbaru Cerdas can submit an application to Baznas Pekanbaru. They can also propose to the UPZ in various government offices within the Pekanbaru Government or UPZ in various offices within the Ministry of Religion of Pekanbaru, by attaching their identity and budget required. For mustahiq who register through UPZ, then UPZ will deliver the prospective recipients of the education program to Baznas. It is then for Baznas to determine the deserved mustahiq by conducting a survey. For those who are chosen as recipients of assistance will be notified by Baznas by telephone, a short message, and/or post an announcement on Baznas Pekanbaru. Then, they can get the zakat by bringing the real and similar identity card as used in the registration. ${ }^{24}$

\section{Program Pekanbaru Sehat}

Program Pekanbaru Sehat, is a form of zakat aiming at helping the cost of health treatment for the poor families that are distributed quarterly and incidental. In 2013, the amount of funds disbursed for this program was IDR 34,000,000. The nominal range of Program Pekanbaru Sehat in that year was IDR 1,000,000 up to IDR 6,000,000. The amount of health assistance provided by Baznas Pekanbaru is adjusted to the number of bills charged to patients who become the mustahiq. The cost of medical treatment provided by Baznas is still relatively small, due to the limited funds that Baznas Pekanbaru has. Therefore, the costs provided are considered as assistance. ${ }^{25}$

Medical assistance provided by Baznas Pekanbaru is based on submissions. If it is provided for purchasing drugs that have been redeemed before, mustahiq can attach a receipt for the purchase or if it is for hospitalized cost, the bill must be submitted. ${ }^{26}$

\section{Program Pekanbaru Peduli}

Program Pekanbaru Peduli is a form of zakat distribution aiming at helping the living costs of the poor and other mustahiq who experience disasters such as

23 Yelmawatil, Gusniar, Yusnawati, Intan, Anggita, Ahmad Zahir, and Rizki S, Mustahiq Zakat, Interview, 16-18 August 2014.

24 Dr. H. Erman Gani, MA, Deputy Chairman of Baznas Pekanbaru, Interview, February 25, 2015.

25 Dr. Akbarizan, Daily Chairman of the Pekanbaru City Baznas, Interview, on 20 August 2015; In Pekanbaru.

26 H. Ismardi Ilyas, M. Ag, Head of the Distribution Section of Baznas Pekanbaru, Interview, January 28, 2015. 
fire and flood; it also included helping travelers who run out of provisions. In 2013, Program Pekanbaru Peduli paid the total amount of IDR 289,823,000. The nominal range of Program Pekanbaru Peduli in 2013 was IDR 1,000,000 up to IDR 1,500,000. Baznas' role in this program is to extend a short-term help, not targeting at solving long-term financial problems. ${ }^{27}$

The mechanism for receiving this zakat is similar with other aid programs i.e. proposing the required costs. Baznas will follow it up by conducting a survey based on feasibility study of the provided costs and finally will determine the amount of money. This disaster assistance can also be done by the Baznas management who come to the disaster location to give out various necessities for the unfortunate people. The direct visit is usually done with the Regional Government delegation. The type of assistance provided in Program Pekanbaru Peduli has alleviated some of the basic needs of mustahiq experienced the disaster. However, the amount ranged between IDR 1,000,000 and IDR 1,500,000 was inadequate since it could not meet the recovery needs after the disaster. ${ }^{28}$

The zakat distribution in the form of Program Pekanbaru Cerdas, Program Pekanbaru Sehat, and Program Pekanbaru Peduli has not been followed by surveillance activities after the assistance was given. As a result, mustahiq's condition after the assistance received is not further supervised by Baznas Pekanbaru.

\section{Productive Program}

A productive program founded by Baznas Pekanbaru is conducted in the form of Program Pekanbaru Makmur. It is a kind of zakat distribution aim to improve the economy through productive business assistance. The amount of funds provided for this program is IDR 391,000,000. In 2013, the nominal range is from IDR $1,000,000$ to IDR 5,000,000. This program is given to mustabiq in the form of productive businesses (venture capital). ${ }^{29}$

The mechanism of receiving this zakat is similar with the consumptive program. Mustahiq must first submit a written request stating his identity along with the details of Rencana Anggaran Biaya (Budget Plan). From the incoming requests, Baznas will then conduct a study and survey, and financing budget will be determined afterward. This means that the provision of venture capital in Program

27 Dr. Akbarizan, Daily Chairman of the Pekanbaru City Baznas, Interview, on 20 August 2015; In Pekanbaru.

28 Rahima, Oyong L, Udin, Yarma Wati, Syamsiar, Delimah, Mariana, Sawiyah, Rosmi, Mawardi, Sulastri D, Zulfikar, Leli S, Jamilla, Nur L, and Syafrizal, Mustahiq Recipients of Program Pekanbaru Peduli, Interview, September 20-27 September 2014.

29 Dr. Akbarizan, Daily Chairman of the Pekanbaru City Baznas, Interview, on 20 August 2015; In Pekanbaru. 
Pekanbaru Makmur, has not been based on a feasibility study, for example what is needed and how much is needed by the mustahiq in building a business, what should he do in advancing his business, including monitoring, controlling and supervising after mustahiq received the funds. Not to mention the evaluation of business development that has not yet been applied by Baznas Pekanbaru. A series of activities have not been carried out above, according to the daily chairman of Baznas, due to the limited operational staff owned by Baznas Pekanbaru.

Some mustahiq of Program Pekanbaru Makmur inform that the funds they receive are used to increase business capital, but it is not significant in increasing income because the benefits obtained are used for daily needs and debt repayment. ${ }^{30}$ Some other mustahiq mentioned that the additional business capital they received was used for the down payment of purchasing motorcycle. ${ }^{31}$ However, there is also a mustahiq stating that the capital received from Program Pekanbaru Makmur was used to start a business of chicken which has been his active income to date. ${ }^{32}$ These various findings of the aforementioned program are due to the lack of supervision and evaluation, as well as the inability to make reports from mustahiq to Baznas.

The implementation of zakat management in Baznas Pekanbaru has not been effective to improve the economy of mustabiq..$^{33}$ This can be seen from the collection of small funds and the lack of application of zakat distribution programs that are able to empower the economy of mustabiq, so that it can change mustabiq

30 Sawinar, Melion, Rosmaniar, Palrisyam, Kadir, Sopian, Nelly F, Edison, Syarianto, Ali Munar, Syafriwal, Nur H, and Gusnimar, Recipients of Pekanbaru Makmur Baznas Pekanbaru City Programs, Interviews, 4-12 October 2014.

31 Kasril and Amri Y, Recipients of Pekanbaru Makmur Baznas Pekanbaru Program Funds, 21 August 2014.

32 Yendra G, Pekanbaru Makmur Baznas Pekanbaru Program Fund Recipient, Interview, August 26, 2014.

33 In fact, only $5 \%$ of the zakat distribution has a significant and positive effect on the income of the mustabiq family. ZIS distribution is able to reduce poverty gap, income index, and poverty severity index. ZIS can also shorten or accelerate poverty alleviation. See Amin Nur Kholid. Dampak Zakat, Infak dan Sedekah (ZIS) Terhadap Penurunan Tingkat Kemiskinan dan Percepatan Pengentasan Kemiskinan (Studi Kasus LAZDAI dan DPU-DT di Bandar Lampung. Jurnal Bina Umat. Vol 1, No 2 (2018): 1-14; Junaidi Safitri. Implementasi Konsep Zakat Dalam al-Quran Sebagai Upaya Mengentaskan Kemiskinan di Indonesia. Jurnal al-Tasyri'. Vol IX, No 1 (2017): 1-15; Galuh Nashrulloh Kartika MR dan Saifullah Abdushshamad. Peran Baznas dalam Distribusi Zaat sebagai Upaya dalam Mengentaskan Kemiskinan. Al-Iqtishadiyab: Jurnal Ekonomi Syariah dan Hukum Ekonomi Syariah. Vol 5, No 1 (2019): 1-9; Nurwati dan Heni Hendrawati. Zakat dan Upaya Mengentaskan Kemiskinan. Cakrawala: Jurnal Studi Islam. Vol 14, No 1 (2019): 40-47; Ahmad Danu Syaputra. Peranan Lazismu dalam Mengentaskan Kemiskinan Masyarakat DIY Yogyakarta. Jurnal Media Ekonomi (JURMEK). Vol 21, No 2 (2016): 1-12; Ridwan dan Muhammad Fadlullah. Zakat, Wasilah untuk Meningkatkan Taraf Hidup Umat dan Pembangunan Nasional. Prosiding Seminar Nasional ASBIS 2017. Politeknik Negeri Banjarmasin, 1-9. 
from its status as a recipient of zakat. ${ }^{34}$ Baznas Pekanbaru can apply the following concepts for the effective management of zakat:

\section{Fund Acceptance Concept}

Islam views poverty as one thing that can endanger the faith, morals, logical thinking, family and society. It means, Islam considers poverty as a disaster that must be tackled immediately. Seeing the danger magnitude the poverty will pose, Islam concentrates on poverty alleviation by finding solutions in various aspects. One of them is the obligation of zakat al-maal for people who have assets within the specified limits (Nisab and haul). ${ }^{35}$

There are at least three variants of zakat management in this voluntary system. The first one is the zakat management by non-government organizations, which are widely available in various countries and Muslim communities. The government can control these institutions as well as other nonprofit controls. This charity is characterized by a high level of donor trust, a strong local character, and high operational efficiency. The activities of these charitable institutions are sometimes able to reach the entire country, even to the international level. The second one is the zakat management by semi-governmental institutions that collect zakat voluntarily and distribute the zakat to those in need. A single example here is Nasser Social Bank (1971) in Egypt. For the management of zakat, the bank

34 Izzah Masruroh and Muhammad Farid. Pengaruh Pengelolaan Ekonomi Produktif dalam Mengentaskan Kemiskinan di Kota Lumajang Studi pada Badan Amil Zakat Nasional (BAZNAS) Kabupaten Lumajang. Iqtishoduna: Jurnal Ekonomi Islam. Vol 8, No 1 (2019): 209-229; Siti Zalikha. Pendistribusian Zakat Produktif dalam Perspektif Islam. Jurnal Islam Futura. Vol 15, No 2 (2016): 304-319; M Shabri Abd Majid. Mengentaskan Kemiskinan Rakyat Aceh dengan Syariah. Jurnal Media Syariah. Vol XV, No 2 (2013): 215-225; Niamulloh dan Akhmad Khisni. Pemberdayaan Zakat dalam Rangka Mengentaskan Kemiskinan Umat (Kajian Menurut UU 23 Tahun 2011 Tentang Pengelolaan Zakat). Jurnal Hukum Khaira Ummah. Vol 12, No 1 (2017): 49-58; Khaerul Aqbar dan Azwar Iskandar. Kontekstulitas Ekonomi Zakat dalam Mengentaskan Kemiskinan: Studi Kebijakan Zakat Umar bin Khattab dan Perzakatan di Indonesia. Jurnal Laa Maisyir. Vol 2, No 2 (2019): 226-245; Aab Abdullah. Strategi Pendayagunaan Zakat Produktif Studi BAZ Kabupaten Sukabumi Jawa Barat. Jurnal al-Tabkim. Vol 6, No 3 (2016): 1-10; Aulia Hilman, Saeful Anwar dan Herman. Implementasi Manajemen Zakat Produktif dalam Upaya Mengentaskan Kemiskinan. Tadbir: Jurnal Manajemen Dakwah. Vol 1, No 4 (2016): 338-354; Akhmad Hafi dan Bayu Wiguna. Sentralisasi Pengelolaan Zakat sebagai Pengentasan Kemiskinan. Tsarwah: Jurnal Ekonomi dan Bisnis Islam. Vol 1, No 1 (2016): 69-84; Hasanuri. Pengembangan Zakat untuk Perekonomian Masyarakat. Al-Abkam: Journal of Islamic Economics and Business. Vol 1, No 2 (2019): 110-122; Muhammad Nasrullah. Peran Zakat sebagai Pendorong Multiplier Ekonomi. Jurnal Hukum Islam. Vol 8 No 1 (2010): 108-119.

35 Zakat was started to be compulsory in Medina on the month of Syawal in the 2nd year of Hijri. About 624 M The collection of zakat was initially run directly by the Prophet Muhammad. See Wahbah al Zuhayli, Fiqh al-Islām Wa Adillatubu, Translated by Abdul Hayyie al-Kattani, Ed 1 (Jakarta: Gema Insani, 2011), 167; Maulidizen, Ahmad. Business Ethics: Analysis of al-Ghazali’s Economic Thought with Sufism Approach. Religia; Jurnal ilmi-ilmu Keislaman. Vol 22, No 2 (2019), 165. 
established a special department for zakat. The bank receives zakat through the local zakat committee or direct payments to the bank's offices and branches. The distribution of zakat is carried out by bank branches and offices based on the recommendation of the local zakat committee. The bank does not take part of zakat funds as 'amil, and the local zakat committee works voluntarily.

The last is the zakat management by government institutions specifically established by the state to receive and distribute zakat. Several countries established zakat management institutions that are legally and financially independent, such as Kuwayti Zakat House (Bayt al-Zakat) in 1982 and Zakat Fund (Shunduk alZakat) in Jordan (1978), Bahrayni (1979), Tunisia and Bangladesh. However, the administrative independence of these institutions varies between countries. The highest independence is owned by Kuwayti Bayt al-Zakat because it is under the Ministry of Waqf.

The obligatory zakat payment system, in which the state's role in managing zakat is dominant and significant, theoretically receives a lot of justification. First, to implement zakat effectively in people's lives, a force that is compelling and regulating is needed. The state has the power to coerce and regulate this. Second, the state has the systems and resources needed to manage zakat effectively and efficiently. This system and government resources are also spread evenly throughout the country which will ensure that zakat is carried out in a fair manner. Third, the state can provide legal certainty and harmonize zakat with taxes. This will ultimately strengthen the institution of zakat. ${ }^{36}$

However, the full management of zakat by this country requires a number of prerequisites. First, the provisions of the Sharia require the management of zakat funds separately from other state budgets, because zakat is specifically distributed only to 8 asnaf (beneficiaries of zakat). This requires strong harmonization in the national fiscal system of contemporary countries which generally have a general state financial system in which all funds that enter the state budget will be combined and channeled regardless of the source of funding and without sorting out its allocation. Second, the state must be based on Sharia. In fiqh's view, only a state based on Islam has the authority to collect zakat by force. Therefore, contemporary Muslim countries which are generally secular countries, are not based on Islamic Sharia, and carry non-Islamic ideologies, do not have the authority to take zakat by force. ${ }^{37}$

36 Wahbah al Zuhayli, Fiqh al-Isläm,...., 155-156.

37 Ibid, 157-158. 
The centralization of zakat management institutions by the state as promoted by the government in the Law No. 23 of 2011 needs to be reviewed for several main reasons $;{ }^{38}$ First, the centralization of zakat institutions by the government does not guarantee an increase in performance, it can even backfire. In many Muslim countries, the collection of zakat by government agencies is small compared to its potential. Even though this centralization was followed by the imposition of sanctions for negligent muzakki, it still could not guarantee a satisfactory increase in the performance of zakat receipts. In Pakistan, Sudan, and Saudi Arabia which implement compulsory systems, the collection of zakat funds is still relatively smaller than its potential. Nonetheless, the performance of compulsory systems is far better than voluntary systems.

Second, the discourse of centralization to improve the performance of zakat is invalid and denies the role of civil society in a democratic society. The performance of collecting and utilizing zakat funds is more determined by the legitimacy and reputation of collecting institutions, not by the centralization of institutions by the government. Transparent company operations and non-profit organizations are preferred and foster trust in muzakki. Trust is the key word here. In the midst of the chaotic reputation of the bureaucracy and low public trust, it is difficult to expect that the performance of zakat will increase post-centralization. This discourse is also historical considering the long track record of non-profit organizations since three decades ago and denying community participation which is an important component in development.

Third, improving the performance of zakat is currently more determined by the success in reducing the leakage of zakat distribution individually, not institutional centralization. Various parties show the enormous potential of zakat. But the realization of the zakat receipt is still far below its potential. The dominant factor of the large gap between the potential and the realization of zakat collection is the distribution of zakat individually, not through institutions, and not related to the institutional centralization of zakat at all. Various studies show that the level of payment of zakat for Indonesian people through institutions is low, below the range of $10 \%$. What should be done is to strengthen government intervention, especially to private parties and entrepreneurs, and to increase public trust in Baznas management and Human Resource, and massive socialization that zakat must be fulfilled through amil zakat institutions, not centralized national zakat institutions.

38 Yusuf Wibisono, Mengelola Zakat Indonesia, Ed 1 (Jakarta: Kharisma Putra Utama, 2015), 160-162. 
Furthermore, among the important requirements that must be met in making the Baznas alms revenue effective are; first, establishing the concept of expansion in zakat obligations. The point is that all assets that develop have a mandatory obligation of zakat and have the potential as an investment for handling poverty. However, this has not been stated directly by the Prophet Muhammad (PBUH). However, the argument for this problem is enough to take the publicity of the obligation of zakat in the Quran and the Hadith. ${ }^{39}$ In one of verses, Allah says "Take $(O$, Muhammad) from their wealth a charity by which you purify them and cause them increase, and invoke (Allah's blessing) upon them. Indeed, your invocations are reassurance for them. And Allah is Hearing and Knowing". ${ }^{40}$

In this verse it is clear that the meaning of assets here includes all assets, because it uses general lafadz and is not limited to certain extent. It includes all types of assets with various names and also a variety of purposes. For those who want to limit the generality of this treasure, then he must put forward his argument. ${ }^{41}$ Every person who has an excess of wealth (the rich) needs purification of their possessions. Purification is done by giving infaq and alms to be able to clear the hearts of their owners from being stingy and selfish. It makes no sense if this purification is only obliged to the owners and farmers of wheat but it is not required for apple, mango or tea growers who have large tracts of land. Or, the owners of factories, apartments and buildings that generate a lot of profit compared with what is produced by plantation farmers whose land is rented land and not fully owned.

39 Yusuf Qardawi, Fiqh al-Zakēt, 93.

40 Surah al-Taubah [9]: 103.

41 Some scholars limit the class of goods required for zakat, but some others extend the obligation of zakat to include all assets considered to be developing. The most extensive scholar describing the class of goods that is required to pay Zakat is Abu Hanifa. He requires zakat on all plant products released from the earth for business purposes in planting. Abu Hanifa does not require nishab and haul for zakat obligation. He also requires zakat on horses and also all animals bred for business purposes and zakat on jewelry. But he does not require all the zakat except for people who have baligh. Therefore, the property of young children and insane people are not obliged to be counted for zakat. As he does not require zakat $1 / 10$ of fertile land with only rain water, so the land that is owned by many Muslims is not used as a source of zakat. Al-Kasany from the Hanafi School said that there is a reasonable and logical 1/10 obligation for results issued from the earth; in fact zakat issued as much as 1/10 of the results obtained and handed over to the poor is a form of gratitude for the favors received and also a form of participation so that people who are weak in the material to remain able to carry out their obligations in worshiping Allah. And this also includes one of purification of sins (including stingy) by giving charity and giving alms. All of this can be accepted by human reason, so zakat is required of all capable and wealthy people, as required of the owners of plantations and fruits without a single difference between the two. See Abdullah Nasikh Ulwan, Zakat. Translated by Abu Bakar (Bandung: Gema Risalah Press, 1988), 48. 
In fact, every asset needs purification from things that doubtful (Syubhat) when he gets it and also in his investment. The purification of this treasure can only be accomplished by issuing zakat, as narrated in the book of Saheeh from Ibn Umar: "Verily, Allab obligates zakat to purify property", ${ }^{2}$ as narrated in some of the hadiths: "If you fulfill your charity, then you have eliminated the crime of evil in it". ${ }^{43}$

Indeed qiyas (Islamic term for deductive analogy) is one of the legal foundations according to jumbur ulama, although Ibn Hazm differed in this regard, because it can analogize all properties for zakat purposes. It can also be emphasized here, that Sharia does not distinguish something of the same type, as it is impossible to unite different things in one law. ${ }^{44} \mathrm{~A}$ Muslim has full rights to his property. For this reason, Allah's right is in the treasure, likewise the rights of people who need help such as the poor who have been specified in the nash. ${ }^{45}$

42 In fact, the treasure in the Islamic view is that everything on earth belongs to God. As for human property, it is a derivation of His possession. Therefore, all people including the poor have rights to the property. This concept includes all the treasures on earth and in the hands of the rich; whether it comes from agriculture, industry, trade or other occupations. HR. Bukhari.

43 It is illogical if the purification of assets is only limited to eight classes of goods - as stated by Ibn Hazm - without involving other classes of assets which have now become sources of income; while on the other hand all types of assets need to be cleansed from the impurity by issuing zakat. It would be unwise if Allah required Zakat to realize this goal by imposing it only on everyone who had five camels or forty goats or five wasaq (each wasaq covers 160 bushels) of wheat, and freed the capitalists, who had large factories, magnificent buildings, extensive trade, doctors and engineers, many workers and also professionals in their respective fields who have income, from the obligation to pay zakat. In fact, what they have is more and abundant than what is produced by someone who only has five camels, five syaq of wheat obtained over the years.

44 Surely no sharia is decided without Allah's will. It is known that zakat is not included in the mahdhah (pure) worship, because it includes the financial management system of society in Islam. Incorporating qiyas into zakat issue is not something new nor is something that has been denied. This has been known since the time of the Companions of the Prophet Muhammad; (a) Umar bin Khattab ordered to take alms from the horse, when he discovered that its value is equal to a large amount of treasure. This opinion was then followed by Abu Hanifah. Zakat is required as long as the horse is bred for business purposes, (b) Ahmad obliged zakat on honey, as told in atsar and also as a form of qiyas for plantations and fruits which are included in the five classes of eight categories of goods that are known for the zakat obligation. He also obliged zakat on all mining goods (gold and silver) as a form of qiyas, (c) Zuhri, Hasan, and Abu Yusuf required zakat on what was from the sea, such as diamond as a form of qiyas on found items and also goods mining, and (d) all mazhab (Islamic schools) include qiyas in zakat. As the Syafi'iyah scholars who adhere to the basic food alms available in a country or the staple food commonly eaten by someone in following up the hadith about zakat fitrah, which obliges zakat on dates, raisins, wheat and poets; or as qiyas of staple food for the aforementioned four types of food. See Muhammad Iqbal, Dinar Solution (Jakarta: Gema Insani Press, 2008), 159.

$45 \mathrm{Ibn}$ Hazm had set the same. It has obliged in the interests of rights other than the rights of charity by enabling the leader right to compel a capable and wealthy person to give some of his wealth to the poor. It also gives rights to the poor to fight hard to get them out of hunger and destruction. In order not to taking much beyond the obligation of charity, it is best to fulfill with the same proportion of 
The Second is about deciding zakat management from permanent and nonpermanent assets. ${ }^{46}$ Permanent asset is the visible one which everyone is able to describe and count. This includes grains and fruits in crops category, and livestock such as camels, cows and goats. Meanwhile, non-permanent property is money or the same as trade items. The scholars differed in the position of zakat fitrah. Some of them consider it a permanent asset, while others consider it non-permanent asset. ${ }^{47}$ Allah said that in every human property, there are other people's rights, without specifying whether the property is the permanent one or not.

Uthman was of the view to collect only from permanent assets. As for nonpermanent assets, Uthman handed over these responsibilities to their respective owners. Uthman placed great trust in them and also in the faith they had. It was also as a form of respect and trust for them by not intervening others' wealth and allowing them to calculate and pay their own zakat. All of this is based on ijtihad carried out by Uthman. If this is ignored in the future by many people until they do not pay zakat on their assets that are not transparent, then it is all due to the lack of religious awareness they have, and also the weak beliefs in their hearts.

\section{Fund Distribution Concept}

Islam is very concerned about poverty. Even poverty is seen as one of the biggest threats to the faith. Islam views that poverty is entirely a structural problem because God has guaranteed the fortune of every creature (al-Rum [30]: 40 and Hud [11]: 6) and at the same time Islam has closed the opportunity for poverty by giving obligations to earn a living for each individual (al-Mulk [67]:15). Every creature has its own sustenance (al-Ankabut [29]: 60) and they will not starve (Taha [20]: 118-119). In Islam, the head of the family has an obligation to meet the basic needs of family members. If it is not done, then the obligation falls to a close relative and if it is still not fulfilled, then the obligation is for the state. Thus, Islam encourages countries to overcome poverty by meeting the basic needs of the community (basic rights approach). ${ }^{48}$

every capable and wealthy person. However, when there are still many unfulfilled needs, the riches have other moral tasks to give more of their wealth out of zakat obligation. See Abdul Qadim Zallum, Sistem Keuangan di Negara Khalifah (Bogor: Pustaka Thariqul Izzah, 2002), 191.

46 There is an opinion that says that compulsory assets are only for permanent ones. Whereas for nonpermanent assets, zakat is only represented by individuals and is not given to zakat institutions which are fully responsible for their distribution.

47 Yusuf Qardawi. Fiqh al-Zakät, 109.

48 Yusuf Wibisono, Yusuf Wibisono, Mengelola Zakat Indonesia ....., 22-23. 
In Islamic perspective, ${ }^{49}$ poverty arises due to various structural causes; (1) human's crimes against nature (al-Rum [30]: 41) so they themselves feel the impact (al-Syura [42]: 30), (2) the ignorance of the rich (Ali Imran [3]: 180, al-Maarij [70]: 18) so the poor are not able to get out of the poverty circle, (3) wrong, exploitative, and oppressing behaviors, such as grabbing others' property in a false way (al-Taubah [9]: 34), consuming orphans' property (al-Nisa' [4]:2, 6, and 10 ), and devouring usury property (al-Baqarah [2]: 275), (4) the concentration of political, bureaucratic, and economic power in one hand. This is illustrated in the story of Fir'aun, Haman, and Qarun who allied in oppressing the Egyptian people during the lifetime of the Prophet Moses (al-Qasas [28]: 1-88) and (5) the external turmoil such as natural disasters or wars so that the country that was originally rich turned poor. Impoverished natural disasters such as those affecting the Saba (Saba' [34]: 14-15) or wars that create poor refugees who were driven out of their country (al-Hasyar [59]: 8-9).

As a mandatory expenditure program in the economy of Islam, the impact of zakat should be significant. There are several reasons for this:

The allocation of zakat fund is clearly established in sharia (al-Taubah [9]: 60) where zakat is only for the eight asnaf; fuqara (fakir), masakin (poor), amilina 'alaiha (management zakat or 'amil), muallaf qulububum (those who are at ease), riqab (liberating slaves), gharimin (debtors), sabilillah (fighters in Allah's path), and ibn sabil (those on the way).Jumbur (majority) scholars agree that apart from these eight asnaf, it is illegal to receive alms. Further, the Quran mentions the poor as the first and second group in the charity list, ${ }^{50}$ therefore, they are prioritized. The main purposes are to solve the problem of poverty and to help the poor. ${ }^{51}$ The importance of eradicating poverty is also agreed by jumbur Scholars (Hanafi, Malik and Ahmad). Hanafi and Malik allow the payment of zakat to just one person among the eight asnaf. Malik adds, giving alms to those who are really in need compared to other groups was sunnah. This characteristic makes zakat inherently pro poor and self-targeted. None of these conventional fiscal instruments has such characteristics.

Zakat is imposed on a broad basis and covers a wide range of economic activities. Zakat is collected from agricultural products, pets, gold and silver reserves, commercial business activities, and mines extracted from the soil. Contemporary figh even states that zakat is also derived from all income generated from physical

49 Ibid., 22-23.

50 Ibid., 24; Nurul Huda, et.al., Zakat Perspektif Mikro-Makro Pendekatan Riset. Ed 1 (Jakarta: Penademedia Group, 2015), 107-108.

51 Yusuf Qardawi, Fiqh Zakät., 510. 
and financial assets and workforce skills. As such, the potential for receiving zakat funds is significant. This is an important capital for financing poverty alleviation programs.

Zakat is a spiritual tax that every Muslim must pay under any circumstance. Therefore, the receipt of zakat tends to be stable. This will ensure the sustainability of the poverty alleviation program, which typically takes relatively long time. ${ }^{52}$

Unlike the Islamic economy which stipulates that the receipt of zakat funds is entirely a source of funding for poverty alleviation program, in the conventional economy there is no earmarked mechanism of government revenue for similar programs as does the zakat system. Ad hoc mechanisms in this conventional system on the one hand provide space for macro-economic policy flexibility. On the other hand, this is a source of uncertainty for poverty alleviation programs.

According to M. Fahim Khan in his book Essays in Islamic Economics, as quoted by Yusuf Wibisono, zakat also plays important role in poverty alleviation through employment creation. The Islamic socio-economic institutional framework encourages job creation through two channels, namely the creation of fixed-wage jobs and entrepreneurial opportunities. One of the most important institutional frameworks in the Islamic economy for job creation is zakat. ${ }^{53}$

In the Islamic economy, financial capital (money) is prohibited from being leased and may not claim interest. The choice to leave financial capital unemployed is difficult because it will be subject to zakat penalties so that it will be reduced every year. The only way for money to not be reduced and to obtain results is by engaging in entrepreneurial activities willingly to bear the risk of the business to earn profits. ${ }^{54}$

52 Wahbah al-Zuhaily, Zakat Kajian Berbagai Mažhab, Translated by Agus Effendi and Bahruddin Fananny. Ed 7 (Bandung: PT. Remaja Rosdakarya, 2008), p. 279

53 Yusuf Wibisono, Mengelola Zakat Indonesia...., 24.

54 The cause of transaction prohibition in Islam is caused by several factors: (1) haram li dratibi, transactions are prohibited because objects (goods and or services) are also forbidden, for example liquor, carcasses, pork, and so on. So, a contract of sale and purchase becomes haram, even though the purchase agreement is legitimate, (2) haram li ghairibi, even though the thing or service being traded is not something forbidden, it can be haram if it violates two things; a) there is fraud in quantity, quality, price, and delivery time. b) violating the principle of wrongdoing (persecuting) and being wronged (persecuted), for example, transacting something that is gharar (unclear), market engineering in supply (ikbtikar); the seller takes advantage above the normal profit by reducing supply; including engineering demand (bay najasy); buyers make counterfeit purchases, as if there were a lot of demand for a product, so that the sale price of the product goes up. Losses of all kinds, gambling, and bribery are also included in violation of the principles of torture and abuse, and (3) invalid (complete) agreement, for example, the terms and conditions are not met, ta'alluq (two terms are intertwined), and two in one (e.g., a transaction is not clear whether to rent or sell). Adiwarman A. Karim, Bank Islam: Analisis Fiqib dan Kenangan. Ed 3 (Jakarta: PT. Raja Grafindo Persada, 2006), 20-49. 
This day, the distribution model of zakat in poverty reduction can be divided into at least two large groups:

1. Distribution of zakat for poverty due to unemployment (a compulsion).

Unemployment occurs because of a compulsion in which a person has no right at all to choose this status, and is required to accept it. This kind of unemployment is like a disaster that is not able to reject it, like other calamities. This kind of unemployment occurs because someone does not have skills, which can be actually learned since childhood for his/her own good. ${ }^{55}$

In general, jabariah unemployment is community and local government's responsibility. However, parents and guardians have not been able to teach them since childhood, which is actually good for children's future. It can also because someone has learned certain skills, but are useless because of environment and time changes. So, he must learn many things that are more appropriate to the age and more useful for the future. ${ }^{56}$ Another possibility is that someone has learned a certain skill, but he needs a lot of supporting tools and equipment that he cannot afford. Like a trader, he needs funds to start his business; or someone who is an agricultural expert, but he does not have the equipment to support farming. ${ }^{57}$

Thus is the guarantor zakat for some Muslims who have not been financially fortunate. For this reason, the zakat role is not just to provide a sum of money or a few kilos of basic food which is only enough to support its recipient within a few days or weeks but after that, they return to their poverty and wait for the mercy of others. Indeed the role of zakat is how a mustabiq can support his self and those who are in his responsibility with his own efforts.

Therefore, every person who has one special skill or has a trade talent is entitled to get the available zakat funds, so that he is able to carry out his profession. In the end, he will be able to get a steady income that could meet his daily needs, even the needs of his family. As for someone who is weak and unable to carry out his skills, profession, or work to earn a living for his life, Islam has established a special law. ${ }^{58}$

Al-Nawawi explained in Majmu' as quoted by Yusuf Qardawi about the level and size of zakat distributed to the poor, "If he is accustomed to doing a certain skill, then he is given zakat to be able to buy all the necessities needed in order to fulfill his skills or to buy his tools, both cheap and expensive ones. In this measure, he is able to

\footnotetext{
55 Karim, Bank Islam., 7.

56 Ibid., 8.

57 Ibid, Asnaini, Zakat Produktif dalam Perspektif Hukum Islam Ed 1 (Yogjakarta: Pustaka Pelajar, 2008), 72-73.

58 Yusuf Qardawi, Daur al-Zakät..., 8
} 
benefit from his efforts. Therefore, this size is different in every profession, skill, region, era and also people who accept it". ${ }^{59}$

However, if a person has not mastered the expertise and skills that can support him in meeting his daily needs, then he is given zakat that is able to sustain his life in accordance with the needs of people his age and the area in which he lives in. These needs are not only measured in a year, but are given for the rest of his life. The gift is not in the form of cash to fulfill his needs in accordance with general standards, but to give something that will earn income every month, for example, giving him a house that he can lease, so as to produce material to meet the cost of living. If the income is still less than what he requires, then he still deserves a part of zakat. All of this is only for people who do not have the expertise and ability to provide their lives. If someone has a particular skill or ability, then he is given zakat in accordance with the price of goods supporting his expertise, even though the price is relatively expensive. ${ }^{60}$

2. Distribution of zakat for poverty due to unemployment of khiyariah (an option).

Unemployed khiyariah is the one who chooses to be unemployed, because he is basically a person who is able to work, yet chooses to be hands-on and lazy that it is burdening for others. He begs but never gives, taking advantage of the people. He chooses to ruin his potential rather than to use it well. He has no business and is a waste of society. Islam is very much against people like this and has little regard for what they do, though many of them state that they are doing this (leaving the obligation to earn a living in the world) to concentrate on the hereafter and only to pray to Allah. Indeed, Islam does not recognize such a world of secularism. ${ }^{61}$

In a statement, Ali bin Abi Talib said, "Making a living in a way that is doubtful (doubtful in its own way) is better than laziness". Furthermore, Abdullah bin Zubair said, "The worst thing in the world is unemployment". ${ }^{62}$ The high priest Manawy (a Sufism expert in his day) recited a hadith that said, "Lo! Allah loves a professional believer (with skill)." ${ }^{63}$ The true Sufism is as exemplified by the

गy Qardaw1., Y.

60 Ibid, 11-12; Wahbah al-Zuhaili, Figh al-Islami wa Adillatubu, Translated by Abdul Hayyie al-Kattani, et.al, Jil 3 (Jakarta: Gema Insani, 2007), p. 288; Rozalinda, Ekonomi Islam Teori dan Aplikasinya pada Aktivitas Ekonomi. Cet 2 (Jakarta: PT. RajaGrafindo Persada, 2015), 268-269.

61 Yusuf Qardawi, Daur al-Zakät..., 13.

62 Qardawi, 14.

63 Ibid; HR. Hakim, Tirmidzi, Thabari, Baihaqi in the book of Sya'ab. Narrated by Ibn Umar. This hadith is a dhaifi (weak) hadith. Shakhawy says: "But he has a lot to say." 
Prophet (PBUH) to one beggar. Anas bin Malik, may Allah be pleased with him, reported that one of the Anshar's men came to the Prophet. The Prophet asked him, "Do you not have anything in your house?" He answered, "Of course, some of the cloth we used, and from some of it we made the basin, as well as the large glass where we drank water from it." The Prophet ordered, "Bring them both to me." Then the two items were given to him and he did an auction by saying, "Who wants to buy these two things?" One man said: "I'll buy it for two dirhams." Then the Prophet sold it and took two dirhams which he then gave to the Anshar men, saying, "Buy food from this one dirham and give to your family, and for another dirham buy an ax and bring it to me." The Prophet strengthened his limbs with his hand, and said to the men, "Go and find the firewood. I don't want to see you again for the next fifteen days." Then the man found the firewood and sold it. Until the time came, he came to the Prophet with ten dirhams in his hand, after which he bought some food. Seeing it, the Messenger of Allah (PBUH) said, "This is better for you than the charity that puts a black stain on your face on the Day of Judgment! Indeed, charity is not lawful except for the three groups, the fagir mudqi, ${ }^{64}$ those who have the mufdzi debt, ${ }^{65}$ and even the muji dam ${ }^{66}$

In this hadith it is clear that the Messenger of Allah (PBUH) did not encourage the men of the Anshar to take part in zakat, when he was able to work. Even charity is not allowed for a person that has many ways and means to meet his own needs. A family member should give him a job opportunity.

Utilization of zakat as described above can apply management theory. Of the many definitions, management referred here is a process or form of work that includes direction of a group of people towards the organization goal. From this definition there are at least four important elements in management i.e. institution, work process, people who do work processes, and the goal.

In collecting zakat, the four elements above are, a) institution includes Baznas, b) work process, the effort to collect zakat, c) people who carry out work processes is 'amil (management) of zakat, and d) the goal is to empower the economy of mustabiq (especially the poor). To do this work, a zakat manager must perform the following management functions; (1) planning by determining the goals within certain time, and what must be done to achieve these goals, (2) organizing

64 Fakir Mudqi: someone who is truly in need. The meaning of mudqi itselt is dust. So what is meant from the word is the devil who sticks to the soil or faqir which is really poor and despicable.

65 The people who have the mufdzi debt are the ones who have the responsibility to pay the deed for what they have done, but they cannot afford it; therefore he is allowed to receive alms by giving him a portion for paying his debt.

66 The Muji Dam is a metaphor for people who have the responsibility of committing a murder, but he cannot afford it and he repents of his actions, so he is allowed to receive alms to pay for it. 
by conducting work groupings or division of tasks in an effort to achieve goals, (3) staffing by determining the personnel or employees needed, their selection, providing training and development, (4) motivating is done to provide enthusiasm and direction to achieve goals, and (5) controlling by monitoring and measuring to achieve the stated goals. ${ }^{67}$

Evading deviations from the goal and turning back to the original goal, in an effort to empower mustahiq zakat, the proper programs must be carried out in accordance with the problems faced by mustahiq. The reason is that poverty can be caused by many things. The poor caused by lack of skills must first be trained according to their talent and ability. The children of poor people who are in school age, must be given the cost of full education. The poor due to difficult job opportunities should be linked by Baznas with certain companies, so that the labor force model they need is known so that the skills provided are in accordance with the needs of the labor market. Of all the zakat programs handled by Baznas, what must not be avoided is supervision. No matter how sophisticated the program is, without monitoring in accordance with the stated objectives, then it can be ascertained that the program will be problematic. The understanding of 'amil needs to be developed into several parts because of the complexity of handling mustahiq, for example, the special institution for education, cooperation, training, assistance, and so forth. The intervention of the government for the implementation of the whole Baznas program is something that cannot be left behind, because from the very beginning zakat is always required to be under the government's responsibility.

\section{Conclusion}

The implementation of zakat management in Baznas Pekanbaru has not been effective in an effort to improve the economy of mustahiq. The inability to receive funds is due to the lack of systemic socialization of zakat activities through Baznas, poor understanding of muzakki on the utilization of zakat, low public trust in Baznas, lack of legal sanctions for muzakki who do not do zakat, and incomplete government intervention. The formula of the effectiveness in terms of receiving zakat i.e. implementing overall government intervention, massive socialization of zakat through Baznas, improving Baznas human resources and management, and applying the concept of expansion in zakat obligations

67 A. Qodri Azizy, Cara Kaya dan Menuai Surga. Cet 1 (Jakarta: Renaisan, 2005), 162-167. 


\section{References}

Abdullah, Aab. Strategi Pendayagunaan Zakat Produktif Studi BAZ Kabupaten Sukabumi Jawa Barat. Jurnal al-Tabkim. Vol 6, No 3 (2016): pp. 1-10

Akbarizan, Daily Chairman of the Pekanbaru City Baznas, Interview, on 20 August 2015; In Pekanbaru

Al-'Asqalani, Ibn Hajar. Bulīgh al-Maräm, Translated by Moh. Machfuddin Aladip. Semarang: CV. Toha Putera, t.th.

Ali, Muhammad Daud. Sistem Ekonomi Zakat dan Wakaf. Jakarta: UI Press, 1998.

Al-Zabidi, Zainuddin Ahmad bin Abdul Lathif, Al-Tajrid al-Shabih li Ahqdits al-Jami' al-Shahih, Translated by Cecep Syamsul Hari and Tholib Anis, Ringkasan Shabih al-Bukhari. Ed 4. Bandung: Mizan, 2002.

Al-Zuhaily, Wahbah. Fiqh al-Islami wa Adillatubu, Translated by Abdul Hayyie alKattani, et.al, Jil 3. Jakarta: Gema Insani, 2007.

Al-Zuhaily, Wahbah. Zakat Kajian Berbagai Maz̧hab, Translated by Agus Effendi and Bahruddin Fananny. Ed 7. Bandung: PT. Remaja Rosdakarya, 2008.

Al-Zuhayli, Wahbah, Fiqh al-Islam Wa Adillatubu, Translated by Abdul Hayyie alKattani, Ed 1. Jakarta: Gema Insani, 2011.

Amelia, Noor. Analisa Potensi Zakat Dalam Upaya Pengentasan Kemiskinan Di Kalimantan Selatan. Jurnal Humaniora Teknologi. Vol 2, No 1 (2016): pp 1-9

Aqbar, Khaerul and Azwar Iskandar. Kontekstulitas Ekonomi Zakat Dalam Mengentaskan Kemiskinan: Studi Kebijakan Zakat Umar bin Khattab dan Perzakatan di Indonesia. Jurnal Laa Maisyir. Vol 2, No 2 (2019): pp. 226245

Aravik, Havis. Esensi Zakat Sebagai Instrumen Finansial Islami Dalam Pandanga Muhammad Nejatullah Siddiqi. Jurnal Economica Sharia. Vol 2, No 2 (2017): pp. 101-112

Asnaini, Zakat Produktif dalam Perspektif Hukum Islam. Ed 1. Yogjakarta: Pustaka Pelajar, 2008.

Azizy, A. Qodri. Cara Kaya dan Menuai Surga. Cet 1. Jakarta: Renaisan, 2005.

Erman Gani, Deputy Chairman of Baznas Pekanbaru, Interview, February 25, 
2015

Fadlullah, Cholid. Mengenal Hukum ZIS (Zakat dan Infaq/ Sedekah). Jakarta: Bazis DKI, 1993.

Hafi, Akhmad and Bayu Wiguna. Sentralisasi Pengelolaan Zakat Sebagai Pengentasan Kemiskinan. Tsarwah: Jurnal Ekonomi dan Bisnis Islam. Vol 1, No 1 (2016): pp. 69-84

Hasan, M. Ali. Zakat dan Infak, Salah Satu Solusi Mengatasi Problema Sosial di Indonesia. Ed 1. Jakarta: Prenada Media Group, 2006.

Hasanuri. Pengembangan Zakat Untuk Perekonomian Masyarakat. Al-Abkam: Journal of Islamic Economics and Business. Vol 1, No 2 (2019): pp. 110-122

Hilman, Aulia, Et,al. Implementasi Manajemen Zakat Produktif Dalam Upaya Mengentaskan Kemiskinan. Tadbir: Jurnal Manajemen Dakwah. Vol 1, No 4 (2016): pp. 338-354

Iqbal, Muhammad. Dinar Solution. Jakarta: Gema Insani Press, 2008.

Ismardi Ilyas, Head of the Distribution Section of Baznas Pekanbaru, Interview, January 28, 2015

Istan, Muhammad. Pengentasan Kemiskinan Melalui Pemberdayaan Ekonomi Umat Menurut Perspektif Umat. Al-Falah: Journal of Islamic Economics. Vol 2, No 1 (2017): pp. 81-99

Kantor Dinas Kependudukan dan Catatan Sipil Pekanbaru. Statistik Jumlah Penduduk. Kota Pekanbaru Tahun 2013.

Karim, Adiwarman A. Bank Islam: Analisis Fiqih dan Kenangan. Ed 3. Jakarta: PT. Raja Grafindo Persada, 2006.

Kartika, Galuh Nashrulloh MR and Saifullah Abdushshamad. Peran Baznas Dalam Distribusi Zaat Sebagai Upaya Dalam Mengentaskan Kemiskinan. Al-Iqtishadiyah: Jurnal Ekonomi Syariah dan Hukum Ekonomi Syariah. Vol 5, No 1 (2019): pp. 1-9

Kasril and Amri Y, Recipients of Pekanbaru Makmur Baznas Pekanbaru Program Funds, 21 August 2014

Kholid, Amin Nur. Dampak Zakat, Infak dan Sedekah (ZIS) Terhadap Penurunan 
Tingkat Kemiskinan dan Percepatan Pengentasan Kemiskinan (Studi Kasus LAZDAI dan DPU-DT di Bandar Lampung. Jurnal Bina Umat. Vol 1, No 2 (2018): pp. 1-14

Lapopo, Jumadin. Majid, M Shabri Abd. Mengentaskan Kemiskinan Rakyat Aceh Dengan Syariah. Jurnal Media Syariah. Vol XV, No 2 (2013): pp. 215-225

Majid, M Shabri Abd. Mengentaskan Kemiskinan Rakyat Aceh Dengan Syariah. Jurnal Media Syariah. Vol XV, No 2 (2013): pp. 215-225

Mardani. Hukum Ekonomi Syariah di Indonesia. Jakarta: Refika Aditama, 2010.

Masruroh, Izzah and Muhammad Farid. Pengaruh Pengelolaan Ekonomi Produktif Dalam Mengentaskan Kemiskinan di Kota Lumajang Studi Pada Badan Amil Zakat Nasional (BAZNAS) Kabupaten Lumajang. Iqtishoduna: Jurnal Ekonomi Islam. Vol 8, No 1 (2019): pp. 209-229

Maulidizen, Ahmad. Economic Thought of Ibn Taimiyah and Relevance to the World Economic and Community Economic System. Esensia: Jurnal Ilmu-ilmu Usbuluddin. Vol 20, No 2 (2019): pp. 131

Muchsin. Masa Depan Hukum Islam di Indonesia. Jakarta: STIH Iblam, 2004.

Mujahidin, Akhmad. Ekonomi Islam. Jakarta: Raja Grafindo Persada, 2013.

Munawwir, Ahmad Warson. Al-Munawwir: Kamus Arab Indonesia. Yogyakarta: Pondok Pesantren al-Munawwir, 1984.

Nasrullah, Muhammad. Peran Zakat Sebagai Pendorong Multiplier Ekonomi. Jurnal Hukum Islam. Vol 8 No 1 (2010): pp. 108-119.

Niamulloh and Akhmad Khisni. Pemberdayaan Zakat Dalam Rangka Mengentaskan Kemiskinan Umat (Kajian Menurut UU 23 Tahun 2011 Tentang Pengelolaan Zakat).Jurnal Hukum Khaira Ummah. Vol 12, No 1 (2017): pp. 49-58

Nopiardo, Widi. Mekanisme Pengelolaan Zakat Produktif Pada Badan Amil Zakat Nasional Tanah Datar. Jurnal Ekonomi dan Bisnis Islam. Vol 1, No 2 (2016): pp. $185-196$

Nur'aini, Zulkifli, Dasril and Rohani, Mustahiq Zakat, Interview, 10 August 2014

Nurul Huda, et.al. Zakat Perspektif Mikro-Makro Pendekatan Riset. Ed 1. Jakarta: Penademedia Group, 2015. 
Nurwati dan Heni Hendrawati. Zakat dan Upaya Mengentaskan Kemiskinan. Cakrawala: Jurnal Studi Islam. Vol 14, No 1 (2019): pp. 40-47

Paradilla, Senda. Revitalisasi Pengelolaan Zakat Pada Badan Amil Zakat Nasional (BAZNAS) Kota Palopo Dalam Meningkatkan Kesejahteraan Mustahik. Dinamis: Journal of Islamic Management and Business. Vol 2, No 1 (2019): pp. 23-36

Prihartini, Faridah, et.al. Hukum Islam Zakat dan Wakaf; Teori dan Prakteknya di Indonesia. Jakarta: Papan Sinar berkerjasama dengan Badan Penerbit FHUI, 2005.

Qardawi, Yusuf. Daur al-Zakät, fi IIlaj al-Musykilat al-Iqtishadiyah, Transleted by Sari Narulita, Spektrum Zakat, Dalam Membangun Ekonomi Kerakyatan. Ed. 1. Jakarta: Zikrul Hakim, 2005.

Qardawi, Yusuf. Fiqh al-Zakät, Transleted by Salman Harun, et.al,. Ed. 6. Bogor: Pustaka Litera Antar Nusa, 2002.

Rahima, Oyong L, Udin, Yarma Wati, Syamsiar, Delimah, Mariana, Sawiyah, Rosmi, Mawardi, Sulastri D, Zulfikar, Leli S, Jamilla, Nur L, and Syafrizal, Mustahiq Recipients of Program Pekanbaru Peduli, Interview, September 20-27 September 2014

Rahman, Afzalur. Doktrin Ekonomi Islam. Yogyakarta: Dana Bakti Wakaf, 1996.

Ridha, Muhammad Rashid. Tafsir al-Manar. Jil 10. Mesir: al-Manar, 1368 H.

Ridwan and Muhammad Fadlullah. Zakat, Wasilah Untuk Meningkatkan Taraf Hidup Umat dan Pembangunan Nasional. Prosiding Seminar Nasional ASBIS 2017. Politeknik Negeri Banjarmasin, pp. 1-9

Rozalinda. Ekonomi Islam Teori dan Aplikasinya pada Aktivitas Ekonomi. Cet 2.Jakarta: PT. RajaGrafindo Persada, 2015.

Safitri,Junaidi.Implementasi KonsepZakat Dalam al-Quran Sebagai Upaya Mengentaskan Kemiskinan di Indonesia. Jurnal al-Tasyri.' Vol IX, No 1 (2017): pp. 1-15

Sari, Elsi Kartika. Pengantar Zakat dan Wakaf. Jakarta: Grasindo, 2006.

Sawinar, Melion, Rosmaniar, Palrisyam, Kadir, Sopian, Nelly F, Edison, Syarianto, Ali Munar, Syafriwal, Nur H, and Gusnimar, Recipients of Pekanbaru Makmur Baznas Pekanbaru City Programs, Interviews, 4-12 October 2014 
Shihab, M Quraish. Membumikan al-Qur'an. Bandung: Mizan, 1992.

Sumitro, Warkum. Hukum Islam di Tengah Kehidupan Sosial Politik. Yogyakarta: Bayu Media, 2005.

Syaputra, Ahmad Danu. Peranan Lazismu Dalam Mengentaskan Kemiskinan Masyarakat DIY Yogyakarta. Jurnal Media Ekonomi (JURMEK). Vol 21, No 2 (2016): pp. 1-12

Syarifuddin. Pendayagunaan Zakat Mal Dalam Mengentaskan Kemiskinan (Studi Kasus mustahiq Kelurahan Manggala Kota Makassar.Jurnal Ekonomi Syariah Indonesia. Vol 8, No 1 (2018): pp. 14-22

Triantini, Zusiana Elly. Perkembangan Pengelolaan Zakat di Indonesia. Jurnal AlAhwal. Vol 3, No 1 (2010): pp. 87-100.

Ulwan, Abdullah Nasikh. Zakat. Translated by Abu Bakar. Bandung: Gema Risalah Press, 1988.

Usman, Suparman. Hukum Islam Asas-asas dan Pengantar Studi Hukum Islam Dalam Tata Hukum Indonesia. Jakarta: Gaya Media Pratama, 2002.

Wibisono, Yusuf. Mengelola Zakat Indonesia. Ed 1. Jakarta: Kharisma Putra Utama, 2015.

Yelmawatil, Gusniar, Yusnawati, Intan, Anggita, Ahmad Zahir, and Rizki S, Mustahiq Zakat, Interview, 16-18 August 2014

Yendra G, Pekanbaru Makmur Baznas Pekanbaru Program Fund Recipient, Interview, August 26, 2014

Zalikha, Siti. Pendistibusian Zakat Produktif Dalam Perspektif Islam. Jurnal Islam Futura. Vol 15, No 2 (2016): pp. 304-319

Zallum, Abdul Qadim. Sistem Kenangan di Negara Khalifah. Bogor: Pustaka Thariqul Izzah, 2002. 